\title{
U.S. Geological Survey Programs in Massachusetts
}

\section{U.S. Department of the Interior U.S. Geological Survey}

The U.S. Geological Survey (USGS), which was established by Congress in the Organic Act on March 3, 1879, provides geologic, topographic, hydrologic, and biologic information to the Nation. This information comprises maps, data bases, and reports that contain analyses and interpretations of water; energy, mineral, and biologic resources; land surface; geologic structures; natural hazards; and the dynamic processes of the Earth.

\section{Nutrient Removal by Salt-Marsh Ecosystems}

Since 1988, the USGS, in cooperation with the Massachusetts Department of Environmental Protection (MDEP) and the Cape Cod Commission, has been tracking the movement of ground water that contains high concentrations of nitrogen from a sewage-treatment facility toward Namskaket Marsh, which is a major salt marsh on Cape Cod (fig. 1). The Namskaket Marsh project will directly benefit the State and regional authorities responsible for the siting and approval of new sewage-treatment facilities in the rapidly developing coastal zone of Massachusetts. Nutrient loading from point and nonpoint sources is a major concern in the coastal zone because such nutrients can ultimately enter coastal waters and cause algal blooms, depletion of dissolved oxygen, fish kills, and general habitat degradation. In baseline studies of the hydrology and chemistry of Namskaket Marsh, the USGS has quantified the distribution and rates of ground-water discharge. Namskaket Creek sediments have been shown to be particularly active zones of ground-water discharge and nitrogen uptake. Moreover, the uptake capacity of these sediments is not fully utilized at present and could increase in response to increased nitrogen loading associated with the adjacent sewage-treatment facility. The USGS, in collaboration with the Woods Hole Oceanographic Institution, also has mapped the natural vegetation communities in the marsh and conducted long-term fertilization experiments to

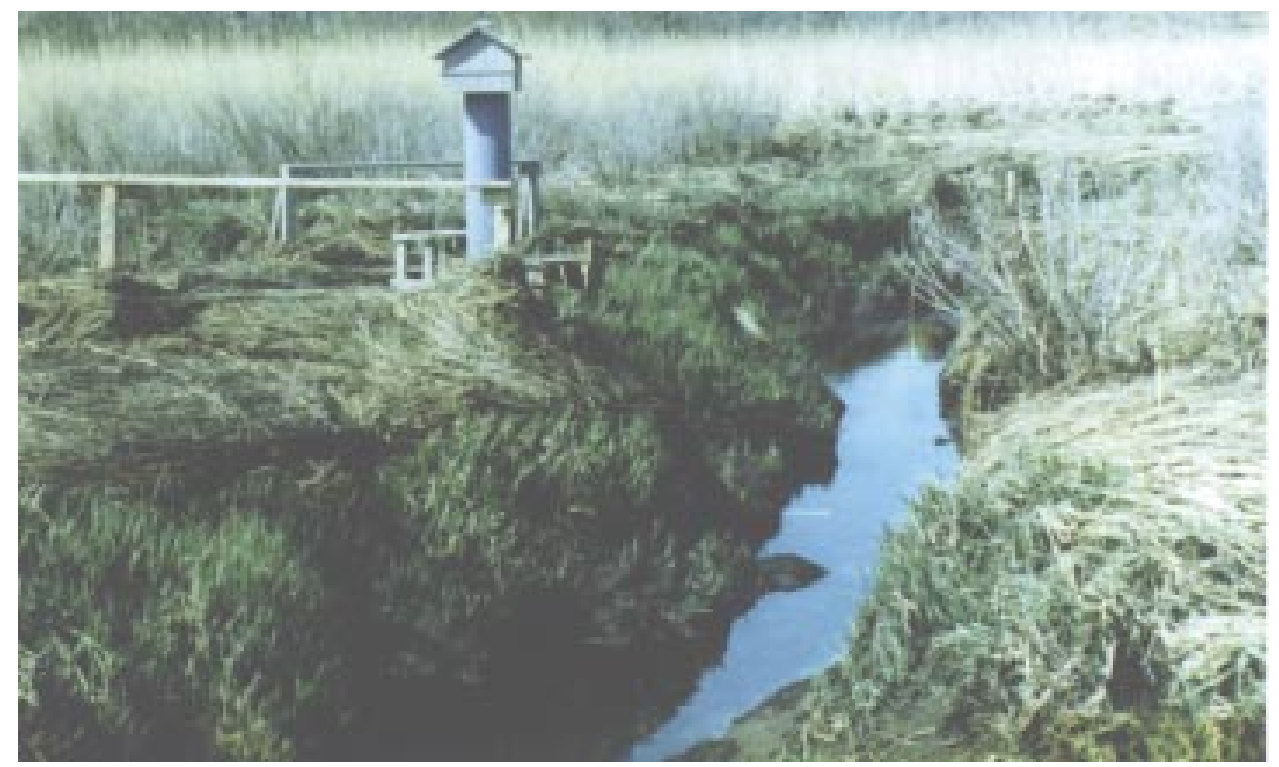

Figure 1. Automated water-level and water-quality monitoring station at Namskaket Marsh, near Orleans, Cape Cod, Massachusetts.

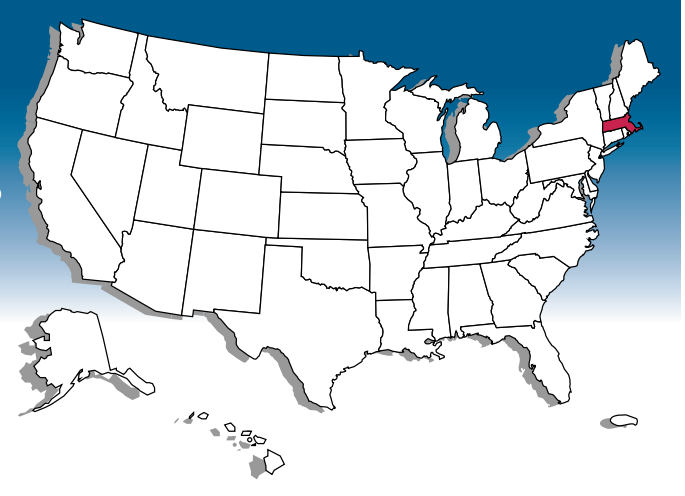

Index of Subjects

Nutrient Removal by Salt-Marsh Ecosystems Fate of Contaminants in Ground Water Availability of Water

Water Quality in the Connecticut River Basin Basins in the Quabbin Watershed

Collection of Hydrologic Data

Topographic Mapping

Earth Science Information Centers

Geologic Mapping

Minerals industry

Marine and Coastal Research at Woods Hole

evaluate the likely response of these communities to increased nutrient loading from ground water. Because a large fraction of the Massachusetts coastline is occupied by salt marshes, the results of the project will have broad significance for wastewater management throughout Massachusetts.

\section{Fate of Contaminants in Ground Water}

Contamination from landfills, sewagetreatment facilities, and other land uses can seriously affect the quality of ground-water resources. Understanding processes that affect the fate of contaminants in ground water is critical for the protection of ground-water resources and the remediation of ground-water contamination.

As part of its Toxic Substances Hydrology Program, the USGS is studying the movement of contaminated ground water that emanates from the Massachusetts Military Reservation (MMR), on Cape $\mathrm{Cod}$, and the complex interaction of hydrologic, chemical, and microbial processes that occur in the contaminated aquifer that underlies the site. Computer models of ground-water flow developed by the USGS for the MMR area were useful to the National Guard Bureau in planning a program to halt the advance of contaminated ground water in seven other areas on the MMR. 


\section{Availability of Water}

The Massachusetts Department of Environmental Management (MDEM) is developing plans to manage water in 27 riverbasin planning units in the State. The USGS, in cooperation with the MDEM, is investigating eight of the planning units and is providing information that is useful to the MDEM in developing these management plans. Reports that summarize the results of investigations such as availability and quality of surface and ground water, interactions between surface and ground water, and transport of sediment by rivers, are prepared as the data become available.

The USGS and the MDEM also are cooperating in two other investigations. Results of one of these will provide data to develop low-flow statistics for Massachusetts streams. The other investigation is obtaining information on the withdrawal, distribution, use, and return of water by municipal, agricultural, commercial, and industrial water users. Information from the USGS-MDEM investigations helps waterresource planners locate potential new water-supply sources, plan and manage for droughts, design wastewater-treatment and other facilities, and assess water withdrawals and interbasin water transfers.

\section{Water Quality in the Connecticut River Basin}

Pollution affects many of the Nation's streams and aquifers. In 1991, the USGS began its National Water-Quality Assessment (NAWQA) Program to describe the quality of many of the Nation's streams and aquifers. Results from one of the regional NAWQA projects, the Connecticut, Housatonic, and Thames Rivers study, include the following:

- Pesticides were commonly found in streams that drain urban areas and large tracts of agricultural land, but concentrations rarely exceeded the detection levels in streams that drain undeveloped areas.

- Twenty-five volatile organic compounds, generally petroleum compounds and solvents, were detected in water from shallow wells that tap glacial sand and gravel aquifers beneath urban areas. The gasoline additive methyl tert-butyl ether (MTBE) was detected in 35 percent of the water samples collected from shallow, urban wells. All MTBE detections were less than 3.0 micrograms per liter.

- Riverbed-sediment samples indicated that seven U.S. Environmental Protection Agency (USEPA) Priority Pollutants, which included antimony, cadmium, copper, lead, mercury, silver, zinc, and sulfur, were at abovenatural levels in areas of intensive urban land use, large population densities, and large numbers of pointsource discharges upstream of the collection point.

- PCB's and DDE (a DDT metabolite) were found in fish tissues sampled throughout the study area, with 28 detections of PCB and 31 detections of DDE at 32 sites. PCB's were found to have the highest levels, particularly on the Housatonic River, where concentrations were more than 10 parts per million at the three sites sampled there.

- A new type of geologic map was developed in which geologic formations are recast into lithochemical units. This map helps in the interpretation of natural water-quality variations owing to the influence of the rock and sediment geochemistry.

\section{Basins in the Quabbin Watershed}

Quabbin Reservoir (fig. 2) provides high-quality drinking water to more than 2.5 million people in 44 communities in central and eastern Massachusetts. About 65 percent of the 96,000-acre Quabbin Reservoir drainage basin is managed by the Metropolitan District Commission (MDC) and preserved as State-owned forest land. The MDC is responsible for protecting the quantity and quality of water that discharges from the drainage basin to the reservoir.

The USGS and the MDC are cooperating to classify small watersheds by land use, topography, geology, soils, and streamwater quality. If similarities among watershed groups can be identified, then hydrologic and water-quality management models can be developed that will apply to watersheds with similar characteristics. Data collected by the USGS, the MDC, the University of Massachusetts, and the MDEP will be used to refine watershed classification.

\section{Collection of Hydrologic Data}

Massachusetts has 27 major river planning basins (fig. 2). To monitor the quantity of water in each basin, the USGS operates and maintains 76 continuous streamflow-gaging stations and obtains monthly ground-water-level measurements from 169 wells. These networks are operated in cooperation with about 10 local, State, and Federal agencies. These data are critical for the daily administration and management of the water resources, determining the extent and severity of droughts, characterizing and predicting conditions during floods, and monitoring the effects of human activities on streamflow and water quality. The data also are used in interpretive studies that provide information critical to decisions about water issues that affect millions of people.

\section{Topographic Mapping}

The use of maps and digital cartographic data is widespread, and requirements for this information are expanding. The National Mapping Program strives to ensure the availability of map data in graphic and digital forms to the public through timely and effective datacollection and revision procedures. Among the most popular and versatile products of the USGS are its 1:24,000scale topographic maps ( 1 inch on the map represents 2,083 feet on the ground). These maps depict basic natural and cultural features of the landscape, such as lakes and streams, highways and railroads, boundaries, and geographic names; contour lines are used to depict the elevation and shape of terrain. Massachusetts is covered by 188 maps at this scale, which is useful for civil engineering, land-use planning, natural-resource monitoring, and other technical applications. The USGS has prepared digital line graph coverage (transportation, hydrography, contours, and boundaries) for about 30 percent of the State.

The National Mapping Program fosters partnerships with State and Federal agencies to improve the effectiveness of its data-collection activities, to maximize resource sharing, and to enhance the availability of timely and accurate data to the general public. The USGS and the Massachusetts Executive Office of Environmental Affairs (EOEA) are involved in a cooperative agreement wherein the USGS 


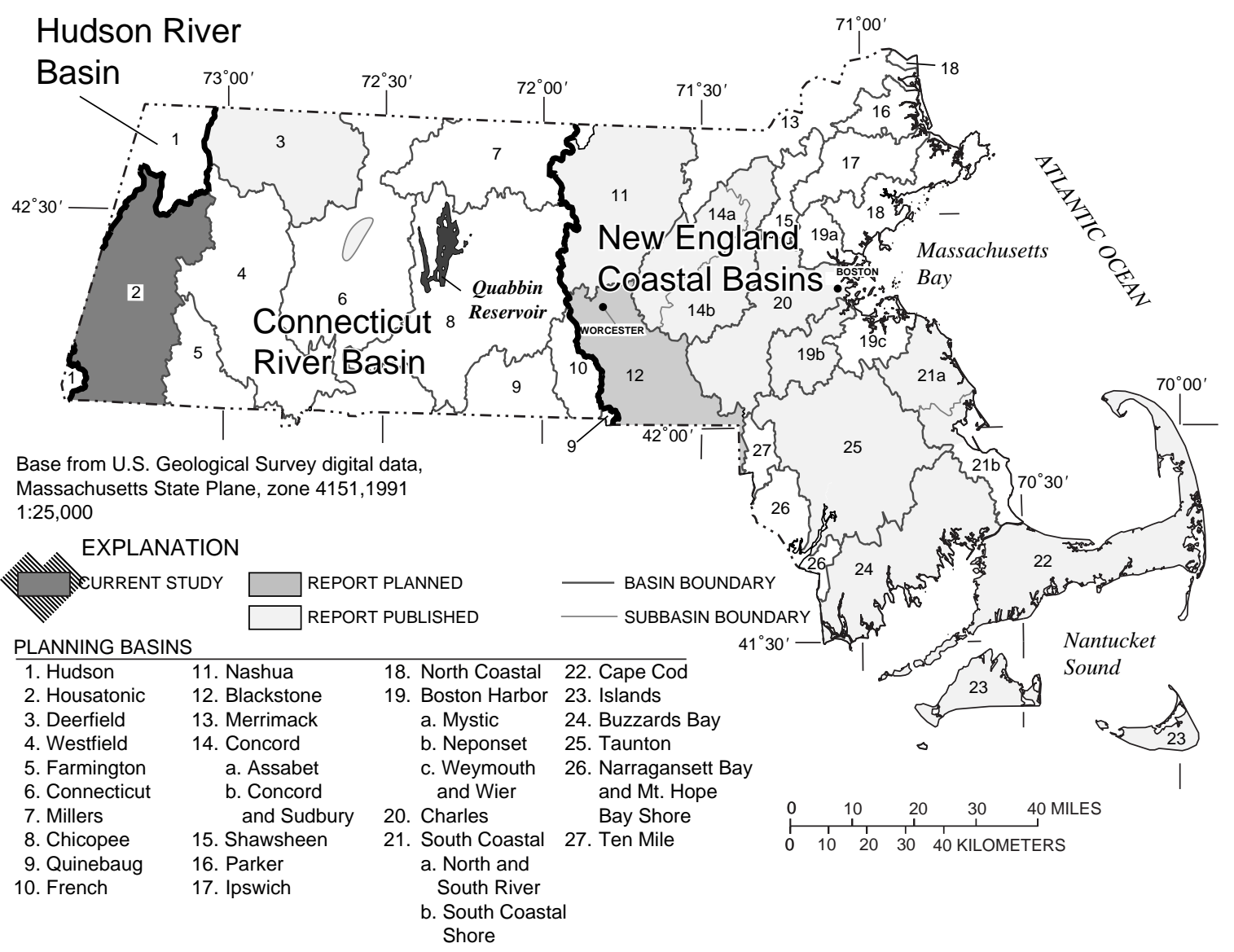

Figure 2. Planning basin boundaries and status of basin hydrology studies and National Water-Quality Assessment study units in Massachusetts, 1996.

provides assistance to support EOEA's preparation of digital orthophotoquads (DOQ's) to meet USGS standards. About 15 percent of the State is being covered by DOQ's under this project. A DOQ is derived from digitized aerial photographs with displacement caused by camera tilt and terrain relief removed. It combines the image characteristics of a photograph with the geometric qualities of a map. DOQ's are becoming increasingly useful as a component in geographic information systems in combination with vector data. The USGS and the EOEA also have collaborated to provide National Aerial Photography Program photographic coverage for the entire State.

\section{Earth Science Information Centers}

The Earth Science Information Centers (ESIC's) provide information about USGS programs, products, and technological developments to the public. The ESIC in Amherst was established under a cooperative agreement between the USGS and the University of Massachusetts. As part of the national ESIC network, this office provides information on such earth science topics as cartography, geography, digital data, remote sensing, geology, geophysics, geochemistry, hydrology, geohydrology, aerial photography, and land use. It is supported by the USGS with reference materials, technical assistance, training and outreach activities, and access to USGS data bases.

\section{Geologic Mapping}

The USGS has produced a set of digital maps that show the distribution of surficial materials and associated urban and suburban land uses. Surficial materials maps are useful to delineate sources of sand and gravel used in construction and aquifers, which are a source of water for human consumption. The maps are based on more than 50 years of cooperative study between the USGS and the State and are used extensively by State and local planning agencies and consultants in addressing environmental issues.

\section{Minerals Industry}

The USGS canvasses the nonfuel mining and mineral-processing industries in the United States for mineral production, mineral exploration, and mine development and other related mineral-production information. Mineral Industry Surveys (MIS's) are produced monthly, quarterly, and annually. Volume 2 of the three-volume Minerals Yearbook, which is a compilation of the annual State MIS's, reports the mineralproduction information by State. In 1995, Massachusetts ranked 39th in the Nation in nonfuel mineral value, or about 0.5 percent of the U.S. total. The leading mineral commodities were crushed stone and construction sand and gravel.

\section{Marine and Coastal Research at Woods Hole}

The USGS conducts geological and geophysical research and mapping investigations of the continental margins of the United States and the world through its Woods Hole Field Center.

The USGS is conducting a study in Boston Harbor and Massachusetts and Cape Cod Bays to understand the transport of sediments in coastal waters. Construction of a new ocean outfall, which is proposed to begin operation in 1998, will change the treated-sewage disposal site 
from Boston Harbor to Massachusetts Bay (fig. 3). The USGS effort will help predict the fate of contaminants in sediments in Massachusetts Bay. The USGS project is coordinated with studies supported by the Massachusetts Environmental Trust, the USEPA's Massachusetts Bays Program, and the Massachusetts Water Resources Authority.

The USGS, in cooperation with the National Oceanographic and Atmospheric Administration, the University of Rhode Island, the Canadian Hydrographic Service, and the University of New Brunswick, is mapping sedimentary environments and biological habitats of Georges
Bank and the Stellwagen Bank National Marine Sanctuary (a newly designated sanctuary located off the coast of Boston; fig. 3). The waters of Georges Bank are highly productive and, at one time, supported a successful fishery. The mapping studies will assist those who are designing monitoring strategies to preserve and manage the environmental resources and fisheries of Stellwagen and Georges Banks. The USGS is studying the transport and accumulation of sediments and contaminants and mapping the geology and sedimentary environments of the seafloor on a regional basis. These regional studies are essential for the wise management of coastal systems.

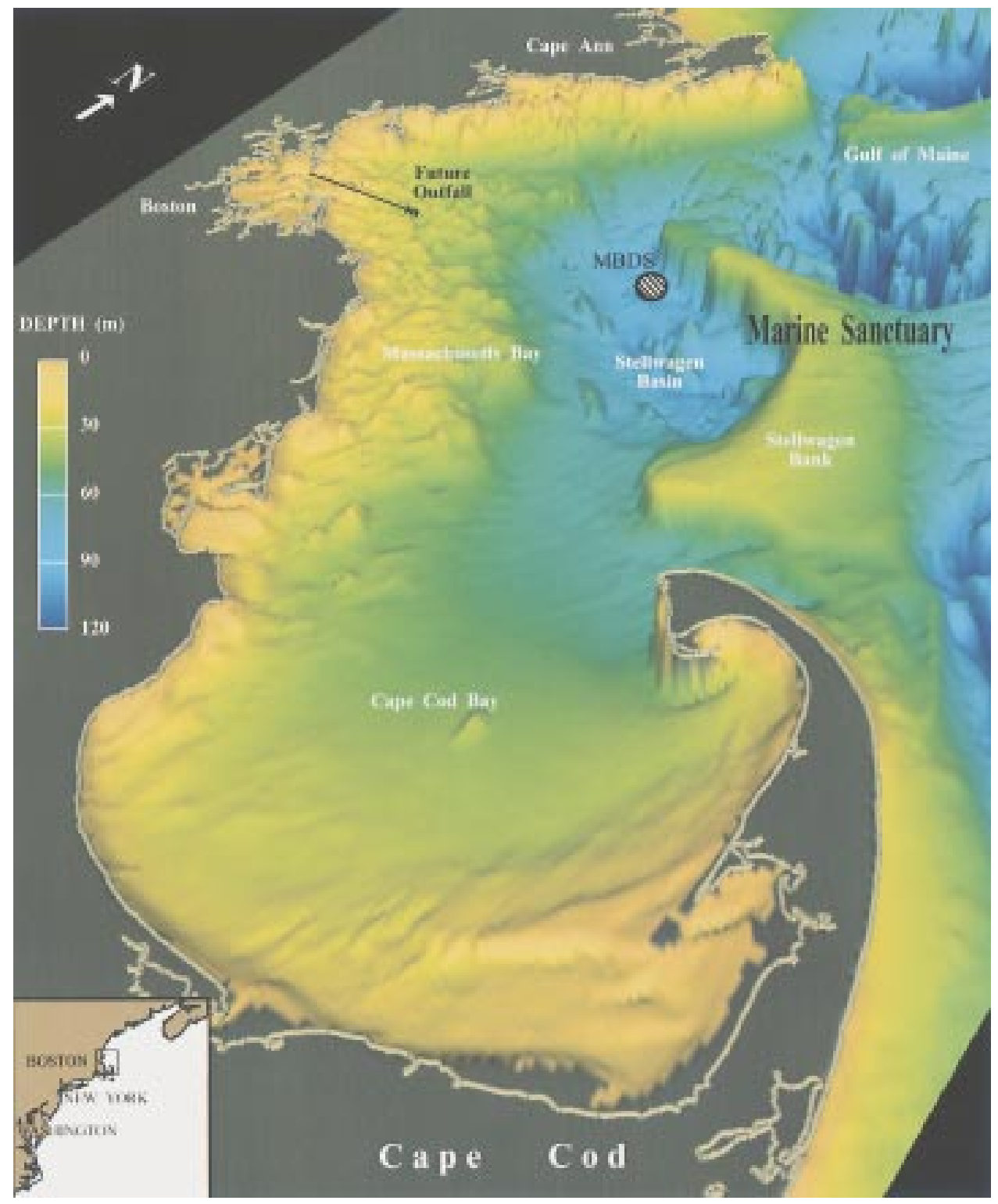

Figure 3. Perspective view of the seafloor topography off Boston, Massachusetts, also showing the location of the Massachusetts Bay Disposal Site (MBDS), which will handle the effluent from the new Deer Island sewage treatment plant. The effluent is expected to be discharged through the outfall beginning in 1997.

For More Information

USGS state representative 28 Lord Rd., Suite 280

Marlborough, MA 01752

Phone: (508) 485-6360

Fax: (508) 490-5068

Email: dc_ma@er.usgs.gov

District Reports and Information: Information Officer

(508) 490-5058

Additional earth science information can be found by accessing the USGS Home Page on the World Wide Web at http://www.usgs.gov/

For more information on all USGS reports and products

(including maps, images, and computerized data), call

1-800-USA-MAPS

The USGS provides maps, reports, and information to help others meet their needs to manage, develop, and protect America's water, energy, mineral, biological, and land resources. We help find the natural resources needed to build tomorrow, and supply the scientific understanding needed to help minimize or mitigate the effects of natural hazards and environmental damage caused by natural and human activities. The results of our efforts touch the daily life of almost every American. 